\title{
LIVING WITH TUBERCULOSIS IN PRISON: THE CHALLENGE TO ACHIEVE CURE ${ }^{1}$
}

\author{
Marcandra Nogueira de Almeida Santos², Antonia Margareth Moita Sá3
}

\footnotetext{
${ }^{1}$ Study extracted from the dissertation - The daily routine of being a carrier of tuberculosis and deprived of freedom: contributions of nursing, presented to the Graduate Program in Nursing at the Universidade do Estado do Pará (UEPA), in 2012.

${ }^{2}$ M. Sc. in Nursing. Nurse Superintendent of the Penitentiary System of Pará. Belém, Pará, Brazil. E-mail: marcandraa@yahoo. com.br

${ }^{3}$ Ph.D. in Nursing. Professor of Undergraduate Nursing at UEPA. Belém, Pará, Brazil. E-mail: margarethmsa@gmail.com
}

\begin{abstract}
The objective of this study was to better understand the meaning, for the person deprived of freedom, of living in prison with tuberculosis and its treatment. The research was conducted using the phenomenological method of Martin Heidegger, applied to 22 interviews realized in five prisons located in the state of Pará, Brazil. The results and its hermeneutics made possible to understand that the person deprived of freedom understands their condition and transcends their facticity and difficulties to achieve the cure of the disease, living as beings of possibilities, revealing their authentic way of facing tuberculosis and its treatment in prison.
\end{abstract}

DESCRIPTORS: Tuberculosis. Therapeutics. Prisons. Nursing. Philosophy.

\section{VIVER COM TUBERCULOSE EM PRISÕES: O DESAFIO DE CURAR-SE}

RESUMO: Objetivou-se compreender os sentidos, para a pessoa privada de liberdade, de viver com a tuberculose e seu tratamento em prisões. A pesquisa foi desenvolvida por meio do método fenomenológico hermenêutico de Martin Heidegger, com realização de 22 entrevistas em cinco prisões localizadas no Estado do Pará. Por meio dos resultados e sua hermenêutica compreendeu-se que a pessoa privada de liberdade entende sua condição e transcende suas facticidades e dificuldades para o alcance da cura da doença, movendo-se como ser de possibilidades e desvelando o seu modo autêntico de viver diante da tuberculose e de seu tratamento em prisões.

DESCRITORES: Tuberculose. Terapêutica. Prisões. Enfermagem. Filosofia.

\section{VIVIR CON TUBERCULOSIS EN LAS PRISIONES: EL DESAFÍO DE ALCANZAR LA CURA}

RESUMEN: Este estudio tuvo como objetivo comprender el significado de vivir con la tuberculosis y su tratamiento en las prisiones. La investigación fue realizada mediante el método fenomenológico hermenéutico de Martin Heidegger. Fueron testigos 22 presos en cinco prisiones ubicadas en el Estado de Para, Brasil. Mediante la hermenéutica se entiende que la persona privada de libertad comprende su condición y trasciende sus facticidades y las dificultades para lograr la cura de la enfermedad, moviéndose como un ser de posibilidades y revelando su auténtica forma de vivir diante de la tuberculosis y su tratamiento en las prisiones.

DESCRIPTORES: Tuberculosis. Terapéutica. Prisiones. Enfermería. Filosofía. 


\section{INTRODUCTION}

Tuberculosis (TB) is an infectious and contagious disease of predominately pulmonary form, ${ }^{1}$ whose highest incidence occurs in the suburban areas of large cities. It is mainly associated with poor living conditions in areas with high population densities, few infrastructural services, nonexistent or inadequate sanitation, closed, dark and poorly ventilated environments, characteristics that are common to prisons in Brazil and around the world. ${ }^{2-8}$

Associated with these environments is the profile of people deprived of freedom, who are mostly young males with low levels of education and previous history of incarceration, illicit drug use and insufficient family income, which increases their risk of developing tuberculosis

In Brazil, the risk of transmission of tuberculosis in prisons is on average 27 times higher than among people considered free, ${ }^{9}$ explaining the need for effective actions to control the disease in those environments. Among the key actions for tuberculosis control is the provision of appropriate treatment for a minimum of six months, with emphasis on strengthening bonds; on sharing responsibilities between people with the disease and professionals; and on the Directly Observed Treatment strategy, for the delivery of quality care, which enables not only the healing of the disease, but the interruption of its transmission in the community. ${ }^{2,10-14}$

Health care in prisons is expressed mostly by prescriptive actions related to the merits of the person deprived of freedom and to the rights granted to them, either by their peers or by healthcare professionals, ${ }^{15}$ to whom it is necessary to promote reflection on the possibilities they have, through the their work, to contribute to reduce the reality of inequality and exclusion that those living in prisons are submitted to. ${ }^{16}$

On the other hand, the number of professionals who work in these environments is reduced, with precarious employment contracts and low wages, which somehow contributes to the high turnover of staff and frailty of the local programs for tuberculosis control. ${ }^{4}$ Within the prison population, factors such as lack of knowledge about the disease, fear, stigma, discrimination and the losses in interpersonal relations provided by this condition interfere with the access to health services or even with the adherence to tuberculosis treatment. ${ }^{17}$
In Brazil, although there is a high rate of people with this disease in prisons, little is described in the health literature about the issue, given the paucity of studies, especially in nursing. ${ }^{18}$ Thus, our concerns have led us to the development of this research, which had as its object of study the daily life of persons with tuberculosis deprived of freedom and whose objective was to understand the meanings of living with this disease and its treatment in prisons. It is believed that the results may help to broaden the understanding of health professionals concerning questions about the health-disease-care process of this population, as well as support discussions for formulating public policies to enhance disease control in prisons.

\section{METHODS}

Qualitative research based on the phenomenological method by Martin Heidegger, using the hermeneutic phenomenology for the analysis of the results. For Heidegger, human existence in the world occurs in the daily way of life, through which we experience others and ourselves. ${ }^{19}$ Phenomenology was adequate for the development of this study for being a descriptive science that does not seek explanations about what there is of its objects of investigation, but "how they are". ${ }^{19-22}$

Heidegger's hermeneutic phenomenology is the interpretation founded on understanding, which seeks to discover the meaning of the way of life of human existence, which can show up on itself and by itself as it is in its essence and not only in appearance. ${ }^{22-23}$ For Heidegger, " $[. .$. existing means interpreting and, therefore, we are interpretation and comprehension in the world of existence and experience $[\ldots]^{\prime \prime} .{ }^{24: 202}$

Heidegger, in his hermeneutics, argues that understanding occurs in a circular structure which is determined continuously by the movement of pre-understanding that we have about the phenomena. On the hermeneutic circle, this pre-understanding may change over the course of an investigation and therefore does not happen in a rigid or unchanging way. ${ }^{19-22}$

The research was conducted in five prisons of the Superintendence of the Penitentiary System of Pará, located in the municipalities of Santa Isabel and Marituba, both in the metropolitan region of Belém, in the period between November 2011 and February 2012. Participants were 22 
men, which consists of the gender of the majority of the state prison population and, therefore, the highest incidence of TB cases. The inclusion criterion was to be in treatment for the disease, at any given time.

After the process of approaching these people, the phenomenological interviews were performed, ${ }^{25}$ in the form of meetings in which the researcher sought to demonstrate to be in the same level of interest of the participants and to establish empathy and mutual respect, which are important to promoting dialogue. The meetings lasted on average 25 minutes and the starting point was the following research question: How do people deprived of freedom experience the treatment for tuberculosis?

Access to prisons, focus of this research, occurred through contact with the prison management and directors of the correctional facilities. Participating individuals were identified with help from the local nursing staff (nurses and nurse technicians). The interviews took place in visiting rooms, ambulatories and administrative rooms and were performed only after an explanation about the study, its objectives and its importance, and once the participants had signed the Free and Informed Consent Form.

Two moments were considered to analyze the speeches, according to Heidegger: the vague and median comprehension and the hermeneutics. In the vague and median comprehension, the speeches were transcribed and, after careful readings, organized into three units of meaning, by which the intention was to emphasize the speeches that best represented the themes emerged and, therefore, the speeches were not reported in its entirety. In hermeneutics, the meanings of living with TB and its treatment for the person deprived of freedom were sought, through interpretation of the speeches with some of Heidegger's ideas outlined in "Being and Time". ${ }^{19}$

The research proposal was submitted to the Research Ethics Committee of the Magalhães Barata College of Nursing, State University of Pará, and approved by the authorization protocol n. 0054.0.321.000-11. In regard to the ethical principles for human research described in the Resolution no. 196/96 of the National Health Council of Brazil, ${ }^{26}$ it was decided to nominate the respondents with the word "interviewee" followed by the number in the sequence in which they participated.

\section{RESULTS}

\section{Vague and median comprehension}

The vague and median comprehension, which is the simplest and most immediate understanding of the subject about the ways they experience and signify the treatment for tuberculosis in prison, is presented after each unit. Some concepts and slang used by the interviewees were clarified with expressions in square brackets.

\section{Experiencing tuberculosis and the difficulties for its treatment in prisons}

It is an obligation for my health [...]. If I want to live, I have to do it, because it's for my health, because if I do nothing for my life, I will not take the medicine. I know that if I do not take it I will get worse, so I feel an obligation. Sometimes I do not want to take it because it is very strong [grimaces]. [...] It makes me dizzy, makes me feel everything, you know? But I have to take it! I'm already sick even of its smell (Interviewee 01).

Many times I think about stop taking this medication [...]. It is harming me, you understand? It gives me itchiness, makes me hungry, and weak [...]. I'm not used to this kind of medication but then, as it is for my improvement, I take it (Interviewee 04).

But when I felt sick, I took the medicine, anyway, took by fits and starts, but I carried on [...] fasting is hard! But we can do it! With willpower we'll get there [...]. I took it because I knew it would do me good. At the end of it was for my good, so I had to keep taking it (Interviewee 22).

When asked about the treatment they perform to fight tuberculosis, patients in prisons recognize it as the only way to achieve biological healing, which, for them, proves to be a personal challenge, since they assume the treatment as a necessary commitment to life, an obligation towards their own health.

For the carrier of tuberculosis deprived of freedom, even when there is manifestation of adverse drug effects, these should not prevent them from proceeding with treatment. Reports of nausea, hungry and itching in the body are insignificant if compared to the signs and symptoms of the disease and therefore need to be overcome, even if there is no timely management of these situations by healthcare professionals working in prisons, considering that the Tuberculosis Control Program guides on this management.

I take it with support, for sure, from my family, 
because if not, if it depended on myself, I would have stopped taking this medication [...] (Interviewee 04).

But with the strength that my mates give me there in the village [in the prison block] [...], they see that I'm doing the treatment and did not deviate too much from me. [...] the support of my wife is what gave me the strength, she did not dump me, it is the strength that people need in here (Interviewee 05).

I believe in God and he will heal me in respect to this [...]. I believe a lot in Him, I pray a lot and I ask him, to take this disease from me (Interviewee 12).

A person, sometimes, goes through a lot of trouble [...]. Today, for example, I have nothing, because everything my daughter brought is gone, then I don't eat correctly (Interviewee 14)

To achieve the goal of healing and restoring the normal coexistence with others, amended by the disease, the person being treated for tuberculosis in prison has the support of family and friends, and of the faith in God to believe in the reestablishment of their health and to continue taking the medication, because the manifestation of the adverse drug effects make them think about quitting the treatment.

For the healthcare practices of persons deprived of freedom and in treatment for tuberculosis to be successful, a complementation to the food that is offered in prison and medications for managing adverse drug effects of the treatment are also needed as social support external to the prison unit that promote continuity of care and of physical and biological response of patients.

\section{Overcoming the obstacles that compromise the cure of the disease}

It gets pretty complicated to heal me here, because it's very stuffy [...] there is also a lot of people there [in the prison block] next to each other (Interviewee 03).

In a difficult situation as in a place like this, which is very hot, it is difficult for the person to be in treatment, but you have to endure, it's like that (Interviewee 19).

Back there [in the prison block] there are people who are sick with that stuff, there are people coming out with tuberculosis, also there are people with many diseases [...] and then what happens? We come here to get medications and there is none (Interviewee 09).

Often I come here to the ward, but there is not the appropriate medication for me, only if it is the $T B$ medication [...]. Sometimes it gives me dizziness, headache, I come here and they cannot give medication, but that's it (Interviewee 04).

People being treated for tuberculosis in prison recognize and point out the limitations of the physical structure of the environments in which they live, which are overcrowded, hot and stuffy. They describe the weaknesses of the health services that are accessible to them and mention the obstacles that make these services precarious, which may contribute to the magnitude that the disease presents in these areas, where it is difficult to treat patients, especially due to the lack of medication that minimize drug intolerance shown by patients, which are common in prolonged treatments.

\section{Experiencing professional embracement for the recovery of health}

I feel very good [...], it is also very good for the attention they are giving to me, you know? It's wonderful (Interviewee 06).

I'm fine now, you know? The care service is better. [...] today I am grateful for the treatment I take [get] [...]. Every time there is medication for me to take, understand? Today I feel well already (Interviewee 11).

With time and with help from them here [professionals] who gave me support, had the right attitude, took me to the hospital, gave me treatment, and then I got better (Interviewee 18).

Despite the difficulties experienced during treatment, structural limitations and fragility of the health services in prisons, persons afflicted with tuberculosis, when receiving care, positively evaluate the service and recognize it as an important support received from the health professionals.

The attention of these professionals is a factor that favors the continuity of treatment, since it somehow allows to strengthen bonds with patients deprived of their freedom. Good health care is defined and described when, for example, there is no interruption in the supply of chemotherapy drugs to combat tuberculosis, which leads, in the view of the deponents, to the expected outcome of being discharged, because the disease was cured.

\section{DISCUSSION}

\section{Hermeneutics}

In search of the ways people deprived of freedom experience the treatment for tuberculosis, and from the speeches and Heidegger's hermeneutic 
phenomenology, a new understanding was possible. According to the philosopher, hermeneutics can lead to the encounter of the sense as a way-ofbeing of the being of Dasein, which can show up in itself and for itself, and which has, by facticity, a possibility for self-understanding. ${ }^{27-28}$

In terms of classical philosophy, Heidegger had his own way of expressing himself. He valued the roots of Greek and German words and used hyphens, which suggest a return to the origins of language, and allow the meaning of the word to be unveiled, uncovered, known. Therefore, some concepts in Heidegger's phenomenology were fundamental for the development of this study:

Entity - is everything we talk about, what we refer to. In the broadest sense, it is any entity. A chair, a table, an animal, a memory, feelings and the man himself are entities.

Ex-sistenz (presence) - term of Greek derivation that means being out, being in a foreign posture. It is the way of being that binds man to the world. The nature of the being of Dasein (beingthere) is related to its ex-sistenz, to the opening of its possibilities. The ex-sistenz is oriented to transcendence, as it projects itself to the world. It is understood as what emerges, unveils, it is the power-to-be.

Being-with/Being-with-one-another - as existential, it concerns our relationships with other entities. It is only possible to "touch" other entity for the entity that has the mode-of-being of presence (the Dasein).

Care - it is the mode of being-with of Dasein, be yourself, be with other Daseins and being-with others inner worldly.

Being-in-the-world - for Heidegger, Dasein and the world are structures that complement each other, designed from the phenomenon of unity. It does not mean, therefore, to think of the Dasein being as a being "in" the world, but a being that composes the world and is also composed by it.

Authenticity - it is the Dasein's mode of being itself, its own way of being that can choose to be itself, conquering itself, or which can annul itself, not conquering or conquering itself in an apparent form.

Ambiguity - it is the mode of being of the being-in-the-world, where there is possibility of dual interpretations of phenomena; it is an oscillating motion with lack of criteria to distinguish the authentic from the inauthentic existence, where everything seems to have been authentically un- derstood, when in fact it was not.

For Heidegger, understanding is the foundation for the interpretation that is based on a previous conception and, therefore, it has already chosen certain conceptualization in a definitive or provisional way. ${ }^{19,23,29}$ Thus, the new understanding of the phenomenon goes beyond what is shown immediately in the existence of human beings, in an interpretation of their attitudes and in the way they experience the world and themselves.

Through the interpretation of the participants' speeches, it was possible to understand that the person deprived of freedom faces many challenges in achieving tuberculosis treatment, however, they almost always seek to overcome these by understanding this resource as the only one for restoring their health. Over time, the damage caused by tuberculosis leads the sick person to strive to return to the past, to life as it was before, to the recovery of their health, even if they may briefly desire to abandon the therapy.

This return to the past is possible because temporality is one of the components of the Dasein being, a term which means, according to Heidegger, the man thought from the relationship that he establishes with his being. Dasein can understand itself through temporality, because with it, they are always involved in being fulfilled with their occupations. In the world, only the human being is temporal. The other entities are called intratemporal because they cannot temporalize or produce themselves in time. ${ }^{19}$

In the everyday life in which Dasein is almost always present, and most of the time, busy with their activities, time is infinite and presented as a straight and orderly line, formed by successive instants, in which the past and the future are kept in accordance with the present. ${ }^{28}$

The time and everything that happens through it allow the patient being treated for tuberculosis in prisons an everyday contact with different ways of understanding and interpreting life. However, the primacy of the present, based on the past and the future, keeps the patient almost always stuck and limited in his own time, without freedom to achieve the possibilities of a more authentic understanding. Heidegger denominated authentic to be the mode of the human being of being himself, existing from himself and for himself. ${ }^{19}$

According to Heidegger, human existence in the world is not lonely. The being-in-the-world is always being-with others. The patient with tuberculosis in prison recognizes the copresence of 
others and values it as essential to their treatment, however, they almost always see their possibilities of being based on the possibilities of those who they live with, configuring an inauthentic mode of being. ${ }^{19}$

In prisons, showing concern about the treatment for tuberculosis means keeping taking care of yourself, and paying attention to other peoples' health, it means showing how much you care, being cautious and anticipating them. Before someone else does it, the patient recognizes the treatment as the way to restore normal contact with the group, in some way, impaired by the disease.

Treatment for tuberculosis in prisons does not happen on a daily reality, but in its own singularity and specificity that are able to make this experience unique. In this routine, many patients distance themselves from their companions and, in their own ways of being inauthentic, they flee from the disease and the possibilities that it represents.

Others, however, conform to the presence of the sick person in treatment, as they understand that tuberculosis can infect or not and that it is useless to escape the possibilities of life. These have a more authentic way of being, which harbors the totality of possibilities of their existence as being-in-the-world, approaching their existentialism, factuality and decay, which also happens somehow as care.

Care consists of the modes of being of the occupation with things and the concern for others, so it cannot be separated from them. Among these modes of being, care is the dominant, because the being of Dasein unveils itself in it. ${ }^{19,29}$ Care is the condition of possibility of the existence, through which it provides the necessary opening of presence as being-in-the-world, who cares about life and, is dedicated to it. Through care, Dasein is an it-self unified, autonomous, through which it is possible to guide its own being and lead its own life. ${ }^{19,29}$

In unsuitable environments for care, such as prisons, where the incidence of TB is higher than in society in general, the health care that is offered to patients being treated for tuberculosis occurs in the mode of being of care that is indifferent and inauthentic, due to the lack of management of drug intolerances and deficiency in infrastructure to provide better living conditions in the prison.

This care, indifferent and inauthentic, subtracts from man its constitution as Dasein, reducing it to objects that need to be dominated and for which, in most cases, the practice of humanity and of the authentic care are not important. In inauthentic care the presence arises in front of the being of the other, to assume its care and to make it dependent, imprisoned and distant from their power-being. In a different way, the authentic care makes Dasein, when arising in front of the being of the other, help him to assume his own care and to become free to be the being of possibilities that he is. ${ }^{19}$

When receiving care, the person undergoing tuberculosis treatment in prison appreciates it, even if the health care is flawed, deficient and imprisons them, increasingly, in their daily mode of not being themselves. Poor care exposes the patient to fend for themselves, and what is wanted is the restoration of health, which should be a common goal for professionals and patients.

Authentic care, in its turn, presupposes the engage-with, and means being responsible for the health and well-being of others, deprived of freedom or not, allowing them to become free for themselves, and based on their freedom, allows the possibility of the freedom of others. Freedom presents itself as possibility of choice of a way of being in which Dasein transcends the world and projects itself in it. This choice is limited, motivated and conditioned by the world itself and is already always compromised by the finitude of the presence. ${ }^{19,29}$

Choosing to perform the treatment, the TB patient in prison sees it as a possibility of transcending his situation, which allows him to recover the soundness of the essential structure of its existence, the being-with. This treatment is somehow within reach for patients as a condition of an obligation, a confrontation that seems to be greater than the one of the patient considered free, because the drugs to combat tuberculosis bring frequent adverse effects and there are no other symptomatic drugs to contain these effects, and yet the person deprived of freedom takes them and endures their consequences, among which the greatest is represented by death, which can occur when the patient is not monitored effectively during treatment.

For these patients, seeking biological healing, even when the strength to endure the unwanted effects of the treatment and, to live with the challenges of daily life in prison, do not come from themselves, but from others; even when their understanding does not encourage to perceive themselves as the main condition for a successful treatment, it is important that their merit to accept 
to participate in it, and their courage to face the adversities to achieve the cure be valued by professionals. Such recognition is perhaps the first step to sharing an authentic care, enabling that when projecting into the world and recognizing their finitude, humans understand their existence and that of those with whom they live, what would allow them to take ownership of their own being, their life, and their story.

\section{CONCLUSION}

This study initiated with our concerns regarding the difficulties for the control of tuberculosis in prison. Our pursuit of an understanding of the modes of existence of persons deprived of freedom who live in these spaces with the disease and its treatment enabled us to be-with these people and share their feelings and experiences in everyday life.

Through vague and median comprehension, it was possible to see that, despite the difficulties experienced during treatment, structural limitations and weak health services in prisons, tuberculosis patients value the care received and the health professionals who work in these environments.

Hermeneutics fostered an understanding that even living mostly on an inauthentic mode of being in daily life, each of these people can understand their condition and transcend their facticities and difficulties to achieve the cure of the disease, moving themselves as being of possibilities and uncovering the authentic way of living in face of tuberculosis and its treatment in prison.

There is a possibility that the health actions available to control the disease are still not sufficient within prisons, as it seems that the treatment received is "poorer" than that offered to those who are outside prisons, considering the complaints about the lack of symptomatic drugs to combat adverse reactions and help support the treatment.

The lack of structure and the different dynamics of prisons should be considered when evaluating the difficulties in the control of tuberculosis, yet there is still a need to review the processes of health work in these settings, in order to introduce a conformation of care that guarantees authentic care for sick people, whose dignity and right to health should not be excluded because of the mistakes they may have committed throughout their existence. The care to be provided must be centered on effective monitoring and treatment, with responsibility and respect to the needs of each person as an individual.

The purpose of this study was not, in any way, to exhaust the discussion on the subject, given its limitations and the impossibility to generalize its results, which are typical characteristics of the qualitative research. Thus, we suggest further studies about the health of persons deprived of freedom in Brazil and around the world to better understand the health-illness-care processes related to these people.

\section{REFERENCES}

1. Farga V, Caminero JA. Tuberculosis. $3^{\mathrm{a}}$ ed. Santiago (CL): Mediterrâneo; 2011.

2. Ministério da Saúde (BR). Secretaria de Vigilância em Saúde, Programa Nacional de Controle da Tuberculose. Manual de recomendações para o controle da tuberculose no Brasil. Brasília (DF): MS; 2011.

3. Souza KMJ, Villa TCS, Assolini FEP, Beraldo AA, França UM, Protti ST, et al. Atraso no diagnóstico da tuberculose em sistema prisional: a experiência do doente apenado. Texto Contexto Enferm. 2012 Jan-Mar; 21(1):17-25.

4. Sánchez AR, Diuana V, Larouzé B. Controle da tuberculose nas prisões brasileiras: novas abordagens para um antigo problema. Cad Saúde Pública. 2010; 26(5):850-1.

5. Awofeso N. Prisons as social determinants of hepatitis $C$ virus and tuberculosis infections. Public Health Rep. 2010 Jul-Aug; 125(4):25-33.

6. Baussano I, Williams BG, Nunn P, Beggiato M, Fedeli U, Scano F. Tuberculosis incidence in prisons: a systematic review. PLoS Med. 2011; 7(12):e1000381.

7. Noeske J, Ndi N, Mbondi S. Controlling tuberculosis in prisons against confinement conditions: a lost case? Experience from Cameroon. Int J Tuberc Lung Dis. 2011 Feb; 15(2):223-7.

8. Waisbord S. Participatory communication for tuberculosis control in prisons in Bolivia, Ecuador, and Paraguay. Rev Panam Salud Publica. 2010 Mar; 27(3):168-74

9. Ministério da Saúde [página na internet]. Campanha de Tuberculose. Brasília (DF): MS; 2012 [atualizado 2012 Mar 26, acesso 2012 Out 15]. Disponível em: http://portal.saude.gov.br/portal/arquivos/pdf/ apresentacao_dia_mundial_tb_26_03_12.pdf.

10. Queiroz EM, Guanilo MCTU, Ferreira KR, Bertolozzi MR. Tuberculose: limites e potencialidades do tratamento supervisionado. Rev Latino-Am Enfermagem [online]. 2012 [acesso 2012 Jun 26]; 20(2). Disponível em: http:/ / www.scielo.br/pdf/ rlae/v20n2/pt_21.pdf.

11. Ministério da Saúde (BR). Secretaria de Vigilância em Saúde, Programa Nacional de Controle da 
Tuberculose. Tratamento diretamente observado da Tuberculose na atenção básica: protocolo de enfermagem. Brasília (DF): MS; 2011.

12. Souza SS, Silva DMG. Passando pela experiência do tratamento para tuberculose. Texto Contexto Enferm. 2010; 19(4):636-43.

13. Chirinos NEC, Meirelles BHS. Fatores associados ao abandono do tratamento da tuberculose: uma revisão integrativa. Texto Contexto Enferm. 2011; 20(3):599-606.

14. Graças EM, Santos GF. Metodologia do cuidar em enfermagem na abordagem fenomenológica. Rev Esc Enferm USP. 2009; 43(1):200-7.

15. Diuana V, Lhuilier D, Sánchez AR, Amado G, Araújo L, Duarte AM, et al. Saúde em prisões: representações e práticas dos agentes de segurança penitenciária do Rio de Janeiro, Brasil. Cad Saúde Pública. 2008; 24(8):1887-96.

16. Irala DA, Cezar-Vaz MR, Cestari ME. Trabalho em saúde com pacientes apenados: sentidos metafóricos gerados no contexto hospitalar. Acta Paul Enferm. 2011; 24(2):206-12.

17. Ferreira Junior S, Oliveira HB, Marin-León L. Conhecimento, atitudes e práticas sobre tuberculose em prisões e no serviço público de saúde. Rev Bras Epidemiol. 2013 Mar; 16(1):100-13.

18. Gois SM, Santos Júnior HPO, Silveira MFA, Gaudêncio MMP. Para além das grades e punições: uma revisão sistemática sobre a saúde penitenciária. Ciência Saúde Colet. 2012; 17(5):1235-46.

19. Heidegger M. Ser e tempo. $5^{\text {a }}$ ed. rev. Petrópolis (RJ): Vozes; 2011.

20. Marcondes D. Iniciação à história da filosofia: dos pré-socráticos a Wittgestein. $13^{\mathrm{a}}$ ed. Rio de Janeiro (RJ): Jorge Zahar; 2010.

21. Santos EM, Sales CA. Familiares enlutados: compreensão fenomenológica existencial de suas vivências. Texto Contexto Enferm. 2011; 20(Esp):21422.

22. Nascimento VR. A filosofia hermenêutica para uma jurisdição constitucional democrática: fundamentação, aplicação da norma jurídica na contemporaneidade. Rev Direito GV. 2009 Jan-Jun; 5(1):147-68.

23. Missaggia JO. As origens do método heideggeriano: o desenvolvimento das indicações formais [dissertação]. Porto Alegre (RS): Pontifícia Universidade Católica do Rio Grande do Sul. Programa de Pós Graduação em Filosofia; 2011.

24. Araujo JL, Paz EPA, Moreira TMM. Hermenêutica e saúde: reflexões sobre o pensamento de Hans-Georg Gadamer. Rev Esc Enferm USP [online]. 2012 [acesso 2012 Jan 15]; 46(1). Disponível em: http://www. scielo. br/pdf/reeusp/v46n1/en_v46n1a27.pdf.

25. Carvalho AS. Metodologia da entrevista: uma abordagem fenomenológica. $2^{\mathrm{a}}$ ed. Rio de Janeiro (RJ): Agir; 1991.

26. Universidade Federal do Rio grande do Sul [página na internet]. Conselho Nacional de Saúde, Resolução n. 196 de 10 de outubro de 1996. Diretrizes e normas regulamentadoras de pesquisas envolvendo seres humanos. Porto Alegre (RS): UFRGS; 2012 [acesso 2012 Maio 20]. Disponível em: http:/ / www.bioetica. ufrgs.br/res19696.htm

27. Monteiro CFS, Paz EPA, Rocha SS, Souza IEO. Fenomenologia Heideggeriana e sua possibilidade na construção de estudos de enfermagem. Esc Anna Nery. 2006 Ago; 10(2):297-300.

28. Abbagnano N. Dicionário de filosofia. São Paulo (SP): Martins Fontes; 2007.

29. Nunes B. Heidegger \& ser e tempo. $3^{\mathrm{a}}$ ed. Rio de Janeiro (RJ): Jorge Zahar; 2010. 